beneficial earthquake, but one such was reported from Cannes by The Times correspondent on July 29. An earthquake shock near the village of Réotier in the Hautes Alpes has removed an obstruction to the water supply which experts for many years have been trying to locate. The village fountain, dry for many generations, is now gushing forth water and the acute water shortage is at an end. On August 13, a small earth tremor was felt at Pwllheli in Wales, but no damage was done. It was probably due to subsidence in underground mine workings.

\section{Scientific Survey of the Cambridge District}

WHILE those who are visiting Cambridge for the first time-and indeed many who are re-visiting their Alma Mater-will have found the little "Concise Guide to the Town and University of Cambridge", originally written by John Willis Clark, of the utmost value and interest, an even wider audience will have welcomed the book "A Scientific Survey of the Cambridge District" specially prepared for the meeting by the local committee in Cambridge and edited by Dr. H. C. Darby. In fifteen chapters, the geology, physiography, climate, biology and history of Cambridge and the Fen District are summarized by specialists, with numerous references to the literature, and with appropriate maps and diagrams. In particular, there are, as would be expected, chapters on the drainage of the Fens and on the Breckland. The fact that this customary survey of the venue of the meeting is now sent out to members a week or so before the meeting opens gives the scientific worker time to learn in advance of the local topics and places likely to be of especial interest to him. The Survey is to be printed as usual in the Annual Report, and additional copies are also on sale (price 2s.).

\section{The Darwin Library at Down House}

THERE is at present a small collection of books, etc., known as the Darwin Library, at Down House, Downe, Kent, the home of Darwin from 1842 until 1882, which is now in the hands of the British Association. The major part of the existing collection consists of Darwin's own library, which belongs to the professor of botany in Cambridge for the time being, and was generously replaced in Down House by Sir Albert Seward during his tenure of that chair, an action confirmed by his successor, Prof. F. T. Brooks. For the rest, the number of Darwinian books in the possession of the Association is not large; whereas inquiries concerning such books are not infrequently made by visitors and others. The Down House Committee of the Association is endeavouring to collect $(a)$ all biographies of Darwin; (b) contemporary works on Darwinian theories and kindred subjects ; further (c) the collection of Darwin's own publications (books and papers) is not complete; and $(d)$ the Committee would gladly receive and preserve contemporary reviews of Darwin's works. Those who may be in a position to offer appropriate books or papers are asked, in the first instance, to communicate particulars thereof to the Secretary, British Association, Down House, Downe, Kent, in order that duplication may be avoided.

\section{German Trans-Atlantic Flight}

THE four-engined German monoplane Brandenburg landed at the Floyd Bennett Field, New York, at 15.54 (New York time) on August 11 after the first successful non-stop flight from Berlin. The time taken for the 3,942 miles' flight was a little more than twenty-five hours. The machine flew over Newfoundland and the Gulf of St. Lawrence, and at noon passed over St. John, New Brunswick. She encountered head-winds coming down the coast from Canada, and was flying at a height of $2,000 \mathrm{ft}$. at 155 miles an hour. The return flight was completed successfully on August 14 in just under twenty hours. The machine is said to have room for twenty-six passengers, and the flight was designed to show the feasibility of commercial non-stop travel between Germany and America. It is an all-metal monoplane with a wing-spread of $108 \mathrm{ft}$., it carries four 720-h.p. engines, and has a cruising speed of 196 m.p.h.

\section{International Geological Congress}

AT the seventeenth session of the International Geological Congress held in Moscow in 1937, the Geological Society of London extended an invitation, which was accepted, to hold the eighteenth session of the Congress in London in 1940. The first circular, which has just come to hand, contains preliminary details of the arrangements proposed. These include sessional meetings in London on July 31-August 8, 1940, and an attractive programme of excursionsalways an important and valuable feature of Congress activity-which will cover most of the important geology of Great Britain and Eire, and will afford the members of the Congress unrivalled opportunity of visiting many of the type-localities under expert guidance. A provisional list of fourteen subjects for discussion at the actual sessional meetings in London is given in the circular. Among these we may note magmatic differentiation, the geology of iron ore deposits, the geology of coal seams, the geology of petroleum, the distribution of early vertebrates, earth movements and evolution, the geological results of applied geophysics and the geology of sea and ocean floors. The organizing committee, mindful of the fact that this important Congress has not met in Great Britain since 1888, is anxious that the arrangements for the meeting in 1940 shall be as widely known and complete as possible. The office and headquarters of the Congress are at the Geological Survey and Museum, Exhibition Road, London, S.W.7, and all communications should be addressed to the general secretaries at that address.

\section{Agricultural Research Scholarships and Awards}

ON the recommendation of the Agricultural Research Council, the following awards of agricultural research scholarships, studentships for research in animal health and veterinary scholarships have been made by the Ministry of Agriculture and Fisheries and the Department of Agriculture for Scotland: Dr. R. E. Taylor (King's College, Newcastle-uponTyne) a three-year research scholarship in plant pathology, the first year to be spent at Cambridge; 
I. F. Storey (Victoria University, Manchester, and the Imperial College of Science and Technology) a one-year research scholarship in plant pathology at the Imperial College; D. C. Thomas (Imperial College of Science and Technology) a two-year research scholarship in entomology, the first year to be spent at Cambridge; G. W. Cooke (University College, Nottingham) a three-year research scholarship in soil chemistry, the first year to be spent at the Rothamsted Experimental Station; M. R. F. Ashworth (Oriel College, Oxford) a one-year research scholarship in soil chemistry at the Macaulay Institute for Soil Research; D. J. Finney (Clare College, Cambridge) a two-year research scholarship in agricultural statistics, the first year to be spent at University College, London; A. N. Worden (Royal Veterinary College, Camden Town) a three-year studentship in animal health, the first period to be spent at the Lister Institute; J. A. Campbell (Downing College, Cambridge) a four-year veterinary scholarship at the Royal Veterinary College, Camden Town; J. L. McGirr (University of Glasgow) a fouryear veterinary scholarship at the Royal Veterinary College, Camden Town. The object of these research scholarships and studentships is to train research workers in agricultural science and the science of animal health, and, in the case of the veterinary scholarships, to enable graduates with honours in science to obtain a veterinary professional qualification, with the view of undertaking research in animal health. This year for the first time two veterinary scholarships have been awarded.

\section{Announcements}

Mr. Hugh LETT, consulting surgeon to the London Hospital, has been elected president of the Royal College of Surgeons of England.

Mr. Sydney A. HuRren, head of the Department of Radio Technology at the Northern Polytechnic, has been nominated, for the third year in succession, for election as president of the Institute of Wireless Technology.

A NEw Institute for Atomic Physics has been inaugurated at the Royal Hungarian University for Technical and Economic Sciences, and Prof. Z. Bay, formerly professor of theoretical physics in the University of Szeged, at present director of the Tungsram Research Laboratory of the United Incandescent Lamp and Electrical Co., has been appointed the first professor of atomic physics.

IN NATURE of August 13, p. 287, reference was made to a record crossing of the Atlantic from east to west by the Queen Mary. On the return voyage, completed on August 14, another record was set up; the Queen Mary's time for the distance from the Ambrose Channel lightship to the Bishop Rock was $20 \mathrm{hr} .42 \mathrm{~min}$., and her average speed $31 \cdot 69$ knots.

The Metro-Goldwyn-Mayer Corporation is to produce a film of the life of Mme. Marie Curie early next year. Mr. Aldous Huxley will prepare the scenario for the film from an account of Mme. Curie's life written by her daughter, Mlle. Eve Curie. It will be recalled that Mlle. Eve Curie was the author of the book entitled "Madame Curie" published this year (see Nature of June 18, p. 1079). Miss Greta Garbo has agreed to play the part of Mme. Curie.

A VALUABLE addition to the collection of statuettes of pioneers of the British Empire in the Imperial Institute, South Kensington, is the figure of David Livingstone (1813-1873), which has been placed in the Northern Rhodesian Court. The cost of the statuette has been defrayed by the Northern Rhodesian Government, to whom a replica is being sent to Livingstone. This statuette, like those of Cabot, Van Riebeeck, Raffles and Brooke, which immediately preceded it in the collection, is a bronze of half lifesize, and the work of Mr. Herbert H. Cawood, of Sheffield.

A Franco-Czechoslovak Medical Congress will be held at Prague on September 15-17. Further information can be obtained from the general secretary, M. A. Ravina, 254 faubourg Saint-Martin, Paris.

THE fifty-first Annual Conference of the Sanitary Inspectors' Association will be held at Edinburgh on September 5-10 under the presidency of Sir Leonard Hill. The subjects for diseussion will include shellfish, inspection of meat, laboratory control of the milk supply, food and drugs legislation, housing, sanitation, atmospheric pollution, the disposal of trade effluents, and a comparison of English and Scottish sanitary practice. Further information can be obtained from the Secretary, 19 Grosvenor Place, London, S.W.1.

ThE thirteenth Italian Congress of Occupational Diseases will be held at Bari under the presidency of Prof. L. Ferrannini on September 10-12, when the following subjects, among others, will be discussed : occupational pathology of aviation; occupational pathology of athletics; adaptability of the Italian workman to the climate of East Africa; results of the application of compulsory insurance against occupational diseases in the first four years. Further information can be obtained from the Secretary, R. Clinica Medica, Bari, Italy.

The Association for Education in Citizenship is arranging two conferences during October. A conference at Birmingham will discuss "The Meaning of Citizenship", and will be held at the University on October 8-10. Mr. Anthony Eden, M.P., and Sir Norman Angell are among the speakers. The second conference will be at Bristol, on "Education for Democracy and the Modern World", on October 14-16. Lord Allen will give the introductory speech on "Democracy-Britain's Need of a Political Religion", and among other speakers are Miss Rathbone, M.P., Prof. N. F. Hall, John Bell, Gordon Barry, W. McG. Eagar and Harold Shearman. Further information can be obtained from the Secretary at the Association's offices, 10 Victoria Street, S.W.1. 